\title{
LITERARY PRIMITIVISM
}


This page intentionally left blank 

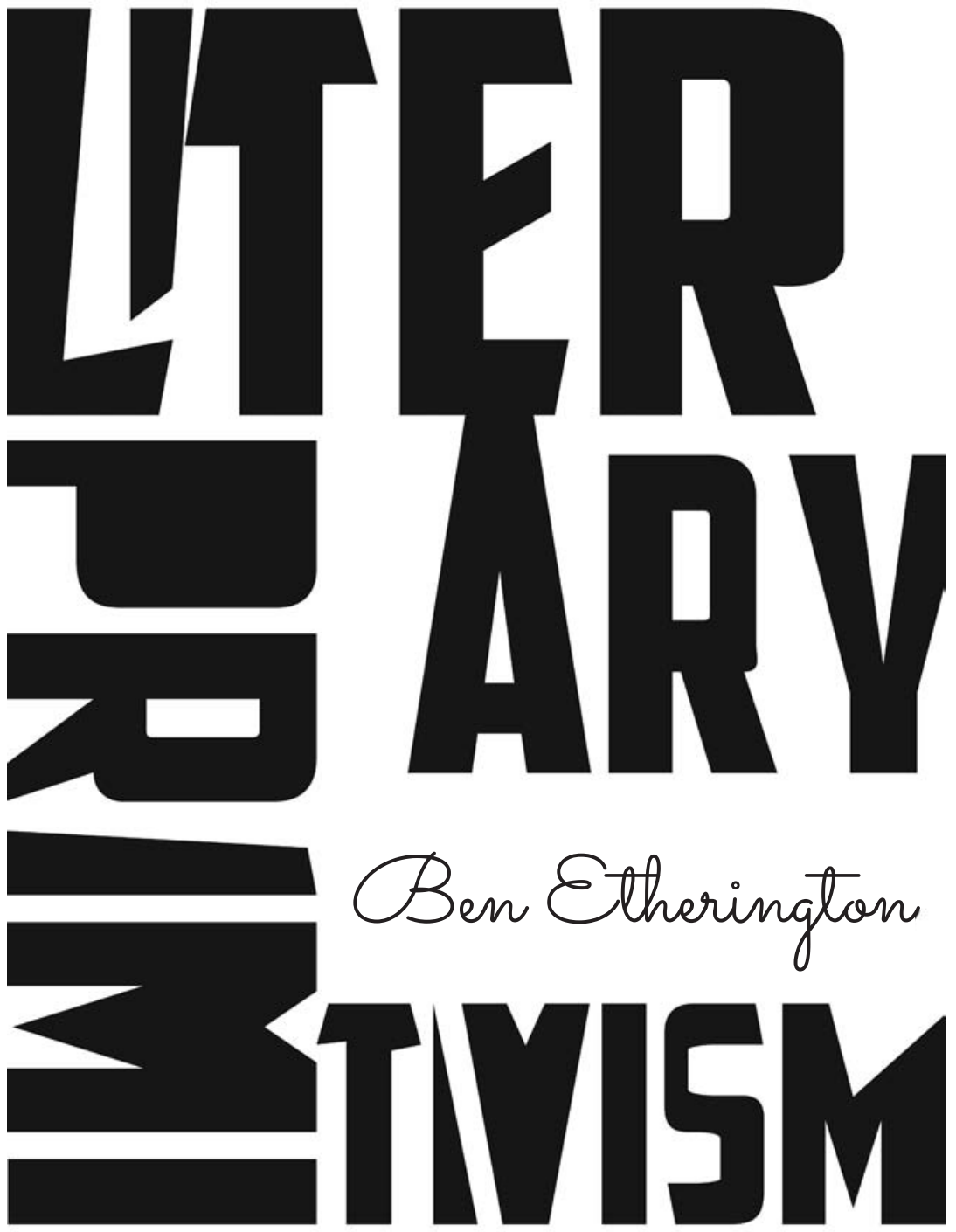

STANFORD UNIVERSITY PRESS

STANFORD, CALIFORNIA 
Stanford University Press

Stanford, California

(C) 2018 by the Board of Trustees of the Leland Stanford Junior University. All rights reserved.

No part of this book may be reproduced or transmitted in any form or by any means, electronic or mechanical, including photocopying and recording, or in any information storage or retrieval system without the prior written permission of Stanford University Press.

Printed in the United States of America on acid-free, archival-quality paper

Library of Congress Cataloging-in-Publication Data

Names: Etherington, Ben, author.

Title: Literary primitivism / Ben Etherington.

Description: Stanford, California : Stanford University Press, 2017. |

Includes bibliographical references and index. |

Identifiers: LCCN 2017028665 (print) | LCCN 2017031111 (ebook) |

ISBN 9781503604094 (electronic) | ISBN 9781503602366 (cloth : alk. paper)

Subjects: LCSH: Primitivism in literature. | Literature-History and

criticism-Theory, etc. | Literature, Modern-2oth century-History and criticism.

Classification: LCC PN56.P7 (ebook) | LCC PN56.P7 E86 2017 (print) |

DDC 809/.9145-dc23

LC record available at https://lccn.loc.gov/2017028665

Typeset by Bruce Lundquist in 10/14 Minion 
For Norman 
This page intentionally left blank 
The Earth has become one place, instead of a romantic tribal patchwork of places.

Wyndham Lewis

Thought remains faithful to the idea of immediacy only in and through what is mediated; conversely, it falls prey to the mediated as soon as it tries to grasp the unmediated directly.

Theodor Adorno

Rediscovering tradition, living it as a defence mechanism, as a symbol of purity, of salvation, the decultured individual leaves the impression that the mediation takes vengeance by substantializing itself.

Frantz Fanon 
This page intentionally left blank 